Artikel Penelitian

\title{
Formulasi Flakes Mohiro dari Mocaf-Beras Hitam dengan Penambahan Kacang Koro Pedang sebagai Alternatif Sarapan Tinggi Protein dan Serat
}

\section{Formula of Mohiro Flakes Made of Mocaf-Black Rice Supplementated with Jack Bean as Alternative Breakfast High Protein and Dietary Fiber}

Friska Citra Agustia*, Yovita Puri Subardjo, Gumintang Ratna Ramadhan, Dika Betaditya

Program Studi Ilmu Gizi, Fakultas IImu-IImu Kesehatan, Universitas Jenderal Soedirman, Purwokerto

${ }^{*}$ Korespondensi dengan penulis (furissuka@yahoo.co.id)

Artikel ini dikirim pada tanggal 28 Juli 2018 dan dinyatakan diterima tanggal 29 Oktober 2019. Artikel ini juga dipublikasi secara online melalui https://ejournal2.undip.ac.id/index.php/jatp. Hak cipta dilindungi undang-undang. Dilarang diperbanyak untuk tujuan komersial.

Diproduksi oleh Indonesian Food Technologists ${ }^{\circledR}$ @ 2019

\begin{abstract}
Abstrak
Penelitian ini bertujuan untuk menciptakan formula terbaik dan menganalisis alternatif sarapan yang tinggi protein dan serat dalam bentuk flakes dari bahan lokal yang terdiri dari mocaf, beras hitam, kacang koro pedang. Perlakuan terdiri atas proporsi mocaf:beras hitam:tapioka masing-masing sebesar 85:10:5; 75:20:5; dan 65:30:5; dan persentase penambahan tepung kacang koro pedang sebanyak $10-30 \%$.Variabel yang dikaji adalah kadar air, kadar abu, lemak total, protein total, kadar karbohidrat, serat pangan,dan nilai energi. Sifat sensori berupa warna, tekstur, aroma kacang dan flavor juga dianalisis. Perlakuan terbaik terdapat pada proporsi mocaf:beras hitam:tapioka dengan rasio 65:30:5 dan dengan penambahan tepung kacang koro pedang sebanyak 10\%. Kandungan air, kadar abu, protein total, lemak total, karbohidrat, serta serat pangan yang dihasilkan dari perlakuan terbaik ini masingmasing sebesar 9,$43 ; 1,43 ; 5,21 ; 4,48 ; 79,44 ;$ dan $15,46 \%$. Hasil uji hedonik diperoleh nilai berkisar dari 3,6 sampai 3,8. Kesimpulannya, formulasi flakes Mohiro dari mocaf-beras hitam dengan penambahan kacang koro pedang dapat ditentukan formulasinya dengan baik dan dapat digunakan sebagai alternatif sarapan tinggi protein dan serat pangan.
\end{abstract}

Kata kunci : mocaf, beras hitam, tepung kacang koro pedang, flakes, sarapan tinggi protein dan serat pangan

\begin{abstract}
This research was objected to determine the best formula and characterize flakes made of mocaf, black rice, and tapioca suplemented with jack bean flour. The treatments consisted of ratio of mocaf:black rice:tapioca i.e. 85:10:5; 75:20:5; and 65:30:5 and 10-30\% of jack bean flour then was added in the dough. Water content, ash content, total fat, total protein, carbohydrate, and dietary fiber were analyzed. Color, texture aroma, and flavor were also analyzed as sensory properties. The best treatment in this study was the flakes with proportion of 65:30:5 with $10 \%$ supplementation of jack bean flour. Water, ash, protein, fat, carbohydrate, and dietary fiber content of the best treatment were 9.43; 1.43; 5.21; 4.48; 79.44; and $15.46 \%$, respectively. The hedonic test value resulted the value between 3.6-3.8. As conclusion, formulation of Mohiro flakes made of mocaf-black rice with jack bean supplementation could be determined and might be used as alternative source of high protein and dietary fiber breakfast.
\end{abstract}

Keywords : mocaf, black rice, jack bean flour, flakes, high protein and dietery fiber breakfast

\section{Pendahuluan}

Sereal merupakan olahan biji-bijian yang dikonsumsi sebagai sarapan dan biasanya dikemas dalam bentuk siap saji atau membutuhkan pemasakan sebelum dikonsumsi, salah satu contohnya adalah dalam bentuk serpihan atau lempengan yang biasa disebut flakes (Caldwell et al., 2016). Berdasarkan SNI 01-427-1996 flakes tergolong dalam kelompok makanan susu sereal, yaitu serbuk instan yang terbuat dari susu bubuk dan sereal dengan penambahan bahan makanan lain dan atau tanpa bahan tambahan makanan yang diizinkan. Flakes biasanya terbuat dari bahan pangan serealia seperti beras, gandum, atau jagung dan umbiumbian seperti kentang, ubi kayu, ubi jalar (Culbertson, 2008). Umumnya di pasaran flakes terbuat dari terigu, sedangkan penggunaan bahan selain terigu lazim dilakukan untuk mengoptimalisasi penggunaan bahan pangan lokal. Penelitian ini menggunakan modified cassava flour (mocaf), beras hitam, dan kacang koro pedang untuk membuat sebuah produk makanan sarapan berbasis pangan lokal yang selanjutnya disebut dengan flakes Mohiro (flakes mocaf, beras hitam, tapioka, dengan penambahan kacang koro pedang). Pemilihan sereal seperti flakes sebagai menu sarapan contohnya yang terbuat dari talas ternyata dapat diterima dan digemari masyarakat karena sifatnya yang praktis dengan rasa yang enak (Sukasih dan Setyadjit, 2012).

Bahan utama pada flakes Mohiro adalah mocaf yang didefinisikan sebagai tepung ubi kayu yang difermentasi dan memiliki karakteristik mirip terigu yaitu fisik lebih putih, lembut, mempunyai cita rasa netral (Sulistyo dan Nakahara, 2014) sehingga dapat digunakan untuk mensubstitusi terigu dalam pembuatan 
produk bakery seperti cookies, biskuit dan flakes AlBaarri et al., 2018). Menurut Supadmi et al. (2016), mocaf memiliki nilai IG rendah dan karbohidrat (pati) $88,61-91,50 \%$ yang dapat mendukung renyahnya tekstur flakes. Penelitian tentang pembuatan flakes dari bahan pangan lokal yang diperkaya sumber protein telah banyak dilakukan diantaranya dari bahan tepung ubi kayu oleh Silva et al. (2011) dengan diperkaya konsentrat protein whey susu, sedangkan Bakar dan Hin (2007), meneliti breakfast tinggi protein yang terbuat dari campuran beras dan kedelai lemak penuh.

Selain mocaf, penelitian ini juga menggunakan beras hitam untuk meningkatkan kadar serat. Menurut Batubara et al. (2017) beras hitam mempunyai kandungan serat pangan (dietary fiber) dan hemiselulosa masing-masing sebesar 7,5 dan 5,8\%, sedangkan beras putih masing-masing hanya 5,4 dan $2,2 \%$. Selain itu menurut Kang et al. (2011) kandungan protein beras hitam yaitu $8,5 \%$ dan beras putih yaitu 6,8 $\%$. Navam et al. (2014), telah berhasil meningkatkan protein pada breakfast sereal dari bahan jawawut dan tepung beras yang diperkaya kacang-kacangan untuk mengurangi kejadian malnutrisi protein pada anak.

Kualitas flakes Mohiro dapat ditingkatkan dengan penambahan bahan berpati misalnya pati tapioka, dimana pati tapioka memiliki daya kembang cukup tinggi, yaitu $\pm 14 \%$ dan nilai cerna pati berkisar $81,3-92 \%$ (Hsieh et al., 2019) sehingga dapat menghasilkan flakes yang lebih lembut, renyah, dan mudah dicerna. Salah satu syarat breakfast (flakes) menurut SNI 01-427-1996 yaitu mengandung protein minimal $5 \%$, sehingga flakes mocaf, beras hitam, tapioka perlu ditambah sumber protein. Menurut Hudiyanti et al. (2015), koro pedang memiliki nilai gizi yang cukup tinggi yaitu total protein, serat, abu, dan kadar air masing-masing sebesar 34; 1,2; 2,8 , dan $12,5 \%$. Kandungan protein koro pedang mendekati kedelai dan memiliki keseimbangan asam amino yang sangat baik serta bioavaibilitas tinggi (Nwokolo, 1996), sehingga dapat dijadikan sumber protein dan menjadi alternatif pengganti kedelai.

Salah satu sifat fisik penting pada flakes adalah kerenyahan. Kandungan amilosa dan amilopektin dalam pati yang berbeda dapat berpengaruh terhadap nilai kerenyahan produk. Menurut Chassagne-Berces et al. (2015), matriks pencampuran antara pati, protein dan serat, dapat membentuk struktur yang kompak dan mengakibatkan tekstur flakes menjadi keras. Flakes yang bertekstur keras dan terlalu kompak dapat dikondisikan menjadi porous, yaitu dengan cara menambahkan $\mathrm{NaHCO}_{3}$ yang dapat menghasilkan gas $\left(\mathrm{CO}_{2}\right)$ saat proses pemanasan sehingga dapat meningkatkan daya kembang dan kerenyahan produk (Agustia et al., 2016a).

Sampai dengan saat ini, belum ada penelitian yang menggunakan berbagai bahan lokal untuk meningkatkan protein dan kualitas flakes, oleh karena itu, penelitian ini bertujuan untuk membuat flakes dari bahan mocaf, beras hitam, tapioka yang diberi penambahan tepung kacang koro pedang. Penelitian ini sangat bermafaat untuk mengetahui proporsi mocaf, beras hitam, tapioka dan persentase penambahan tepung kacang koro pedang yang tepat guna menghasilkan flakes Mohiro dengan kadar protein dan serat pangan yang tinggi serta memiliki sifat sensori yang disukai.

\section{Materi dan Metode \\ Materi}

Bahan yang digunakan pada penelitian ini antara lain mocaf yang diperoleh dari Banjarnegara, kacang koro pedang diperoleh dari Bogor, beras hitam, tapioka, gula halus, garam, natrium bikarbonat diperoleh dari toko roti modern di Purwokerto, serta beberapa bahan kimia untuk analisis. Alat yang digunakan antara lain timbangan analitik (Ohaus, China) oven elektrik, oven (Memmert, Jerman), blender, ayakan stainless steel 60 dan 80 mesh, noodle maker (Atlas, Indonesia), alat masak skala rumah tangga; dan berbagai alat gelas untuk analisis kimia seperti pipet mikro, cawan porselen, tanur, labu takar, desikator gelas, penjepit, soxhlet (Iwaki, Indonesia), labu kjeldahl, alat destilasi, labu erlenmeyer, gelas ukur, vortex MSI, dan buret.

\section{Metode}

Penelitian dilakukan bulan April sampai Agustus 2018 di Laboratorium Penyelenggaraan Makanan Program Studi IImu Gizi dan Laboratorium Teknologi Pengolahan, Jurusan Teknologi Pertanian, Universitas Jenderal Soedirman, Purwokerto. Penelitian menggunakan rancangan acak kelompok. Perlakuan terdiri dari proporsi mocaf:beras hitam:tapioka $(\mathrm{P} ; \mathrm{b} / \mathrm{b})$ yaitu $\mathrm{P} 1=85: 10: 5, \mathrm{P} 2=75: 20: 5, \mathrm{P} 3=65: 30: 5$ dan penambahan tepung kacang koro pedang $(\mathrm{K} ; \mathrm{b} / \mathrm{b})$ yaitu $\mathrm{K} 1$, K2, K3 masing-masing sebesar 10, 20, 30\%. Dari dua faktor diperoleh 9 perlakuan yaitu $\mathrm{P} 1 \mathrm{~K} 1, \mathrm{P} 1 \mathrm{~K} 2$, P1K3, P2K1, P2K2, P2K3, P3K1, P3K2 dan P3K3. Tiap perlakuan diulang dua kali sehingga diperoleh 18 kombinasi perlakuan.

\section{Proses Pembuatan Tepung Beras Hitam}

Beras hitam disortasi kemudian dicuci bersih untuk menghilangkan kotoran yang masih melekat. Selanjutnya dikeringkan menggunakan cabinet dryer hingga kering patah $\left( \pm 24\right.$ jam) dengan suhu $55-60^{\circ} \mathrm{C}$, kemudian dikecilkan ukurannya dengan cara digiling, lalu diayak menggunakan ayakan ukuran 60 mesh. Tepung beras hitam kemudian disimpan di wadah tertutup rapat dan disimpan sampai saatnya digunakan (Croitoru et al., 2018).

\section{Proses Pembuatan Tepung Kacang Koro Pedang}

Pengupasan kulit kacang koro pedang dimulai dengan cara memasukkan kacang ke dalam kain saring dan diikat menggunakan tali atau karet, kemudian dimasukkan ke dalam larutan $\mathrm{NaOH} 3 \%$ mendidih selama 7-8 menit, lalu dicuci menggunakan air mengalir sambil diremas-remas sampai pHnya netral dan terkelupas kulitnya. Setelah itu, steam blanching dilakukan pada kacang koro pedang tanpa kulit selama 30 menit lalu diiris tipis sebelum selanjutnya dikeringkan menggunakan cabinet dryer pada suhu $55-60^{\circ} \mathrm{C}$ selama 土24 jam atau sampai kering patah. Tahap akhir, 
dilakukan penggilingan dan pengayakan menggunakan ayakan 80 mesh. Tepung kacang koro pedang yang lolos ayakan selanjutnya disimpan rapat sampai digunakan (Agustia et al., 2016a).

\section{Proses Pembuatan flakes Mohiro}

Mocaf:beras hitam:tapioka dan tepung kacang koro pedang dengan proporsi sesuai perlakuan dicampur rata dengan bahan lain yaitu margarin, gula halus, garam, natrium bikarbonat, ovalet, vanili, dan air sampai terbentuk adonan homogen. Setelah itu dilakukan pengukusan (steam blanching) selama 15 menit untuk pre gelatinisasi, lalu dimasukkan noodle maker untuk dipipihkan dengan skala 3 (dengan ketebalan $\pm 1 \mathrm{~mm}$ ). Proses selanjutnya, dilakukan pencetakan dengan ukuran $1,5 \times 1,5 \mathrm{~cm}$ lalu ditata dalam loyang dan dipanggang dengan suhu $130^{\circ} \mathrm{C}$ selama \pm 20 menit. Flakes Mohiro kemudian dikemas rapat sampai siap untuk dianalisis (Sukasih dan Setyadjit, 2012). Formula flakes Mohiro sesuai dengan perlakuan dapat dilihat pada Tabel 1.

\section{Prosedur Analisa Proksimat}

Analisis proksimat yang dilakukan meliputi kadar air (metode oven), kadar abu (metode gravimetri), kadar protein (metode micro-Kjeldahl), kadar lemak (metode Soxhlet) dan karbohidrat by difference (Soedarmadji et al., 1997) serta serat pangan (metode enzimatis).

\section{Prosedur Analisa Sensori}

Uji sensori dilakukan berdasarkan pada peneliti sebelumnya (Mozkowitz et al., 2012) yang dilakukan untuk menentukan tingkat kesukaan dari tekstur, rasa, aroma dan flavor dari flakes Mohiro yang diujikan tanpa adanya susu. Uji dilakukan oleh 50 orang panelis semi terlatih yang sebelumnya diberi pengarahan sehingga panelis paham mengenai parameter yang diuji. Uji menggunakan metode skoring. Pengujian menggunakan nilai kuantitatif dengan skor yang telah ditentukan sebelumnya yaitu pada range antara 1 (skor terendah) yaitu tidak suka sampai 5 (skor tertinggi) yaitu sangat suka.

\section{Analisis Statistik}

Data variabel kimia dianalisis dengan menggunakan analisis of variance (ANOVA) atau uji $F(F$ test) pada tingkat kepercayaan $95 \%$. Jika berpengaruh nyata, analisis dilanjutkan menggunakan Duncans
Multiple Range Test pada tingkat kepercayaan 5\%, sedangkan data variabel sensori dianalisis menggunakan uji Friedman. Kombinasi perlakuan terbaik ditentukan menggunakan metode indeks efektifitas.

\section{Hasil dan Pembahasan \\ Kadar Air dan Kadar Abu Flakes Mohiro}

Data menunjukkan bahwa proporsi mocaf:beras hitam:tapioka dan persentase penambahan tepung kacang koro pedang serta interaksi keduanya, tidak memberikan pengaruh yang nyata terhadap kadar air dan abu flakes mohiro (Tabel 2). Kadar air yang dihasilkan dari flakes Mohiro adalah berkisar 9,06$11,84 \%$. Hal ini tidak sesuai dengan syarat mutu flakes SNI 01-427-1996, yang menyaratkan kadar air flakes maksimal $3 \%$. Produk yang membutuhkan tekstur renyah seperti flakes diharapkan memiliki kadar air $<10 \%$ (Culbertson, 2008). Kadar air yang tinggi pada flakes ini dapat diakibatkan karena proses pemanggangan yang kurang sempurna. Tingginya kadar air menjadi keterbatasan pada produk flakes Mohiro ini, sedangkan kisaran kadar abu flakes Mohiro yaitu 1,34 sampai $1,94 \%$ bk. Kadar abu flakes Mohiro dinilai sudah sesuai dengan syarat mutu SNI yaitu maksimal $3 \%$. Hal ini sejalan dengan penelitian Sukasih dan Setyadjit (2012), yang menghasilkan flakes yang terbuat dari tepung komposit talas, pisang, dan kacang hijau dengan kadar abu berkisar $1,7-2,36 \%$.

\section{Kadar Protein dan Lemak}

Data kadar protein dan lemak flakes Mohiro dapat dilihat pada Tabel 2. Data menunjukkan bahwa proporsi mocaf : beras hitam : tapioka dan penambahan tepung kacang koro pedang tidak berpengaruh nyata terhadap kadar protein dan lemak flakes Mohiro. Kadar protein flakes Mohiro berkisar $3,33 \pm 0,8-8,12 \pm 3,61 \%$. Kandungan protein flakes tampak cenderung makin tinggi seiring dengan penambahan kacang koro pedang. Menurut Ariantoro et al. (2016), tepung kacang koro pedang mengandung protein berkisar $24-28 \%$, yang menyebabkan kadar protein flakes Mohiro semakin meningkat dengan semakin banyaknya persentase penambahan kacang koro pedang. Hal ini sejalan dengan penelitian Agustia et al. (2018) bahwa tiwul instan dari proporsi tepung ubi kayu:tepung kacang koro pedang:susu skim (65:35:5) memiliki kadar protein sebesar $8,84 \% \mathrm{bb}$, sedangkan $\mathrm{mi}$ yang terbuat dari

Tabel 1. Formula flakes yang dibuat dengan menggunakan mocaf, beras hitam, tapioka dengan penambahan koro pedang

\begin{tabular}{lccccccccc}
\hline Bahan & P1K1 & P1K2 & P1K3 & P2K1 & P2K2 & P2K3 & P3K1 & P3K2 & P3K3 \\
\hline Mocaf & 85 & 85 & 85 & 75 & 75 & 75 & 65 & 65 & 65 \\
Beras Hitam & 10 & 10 & 10 & 20 & 20 & 20 & 30 & 30 & 30 \\
Tapioka & 5 & 5 & 5 & 5 & 5 & 5 & 5 & 5 & 5 \\
Tepung koro & 10 & 20 & 30 & 10 & 20 & 30 & 10 & 20 & 30 \\
pedang & & & & & & & & & \\
Margarin & 5 & 5 & 5 & 5 & 5 & 5 & 5 & 5 & 5 \\
Gula halus & 30 & 30 & 30 & 30 & 30 & 30 & 30 & 30 & 30 \\
Garam & 1,2 & 1,2 & 1,2 & 1,2 & 1,2 & 1,2 & 1,2 & 1,2 & 1,2 \\
Na bikarbonat & 0,5 & 0,5 & 0,5 & 0,5 & 0,5 & 0,5 & 0,5 & 0,5 & 0,5 \\
Ovalet & 5 & 5 & 5 & 5 & 5 & 5 & 5 & 5 & 5 \\
Vanili & 0,5 & 0,5 & 0,5 & 0,5 & 0,5 & 0,5 & 0,5 & 0,5 & 0,5 \\
\hline Jumlah (g) & 150 & 160 & 170 & 150 & 160 & 170 & 150 & 160 & 170 \\
\hline
\end{tabular}


tapioka dan tepung koro pedang putih dengan perbandingan 80:20 memiliki kadar protein sebesar 7,15\% bk (Murdiati et al., 2015).

Kadar lemak flakes Mohiro cukup rendah, yaitu berkisar 3,05 $\pm 0,49-5,56 \pm 2,99 \%$ bb (Tabel 2). Rentang ini dinilai rendah yang dapat diakibatkan oleh rendahnya kandungan lemak pada bahan penyusun flakes, yaitu kadar lemak mocaf sebesar 0,4-1,9\% (Andriansyah et al., 2017), koro pedang sebesar 2,4\% (Hudiyanti et al., 2015), dan beras hitam yaitu sebesar $1-2 \%$ (Kang et al., 2011). Nilai lemak flakes Mohiro tidak sesuai dengan syarat mutu SNI yaitu minimal $7 \%$. Rendahnya kadar lemak pada flakes ini dapat ditingkatkan dengan cara diseduh menggunakan susu yang kaya akan lemak saat mengkonsumsinya.

\section{Kadar Serat Pangan}

Serat dalam makanan lazim disebut sebagai serat pangan atau dietary fiber yang sangat baik untuk kesehatan manusia. Menurut Kusharto (2006), istilah dietary fiber digunakan untuk membedakan serat pangan dengan serat kasar atau crude fiber, yaitu semua polisakarida dan yang tidak terhidrolisa oleh kerja sekresi usus manusia. Berdasarkan Tabel 2, perlakuan proporsi mocaf, beras hitam, tapioka, dan persentase penambahan tepung kacang koro pedang tidak berpengaruh nyata terhadap kadar serat pangan flakes Mohiro. Menurut Baker dan Holden (2006), lebih dari $75,3 \%$ merk ready to eat breakfast cereal memiliki kandungan serat pangan kurang dari $5 \%$. Sukasih dan Setyadjit (2012) melaporkan flakes yang terbuat dari tepung talas, pisang, kacang ijo dengan proporsi 70:10:20 telah menghasilkan nilai kadar serat pangan sebesar $8,07 \%$. Kandungan serat pangan flakes pada penelitian ini dinilai cukup tinggi, yaitu berkisar $13,32 \pm 1,73-17,43 \pm 3,86 \%$ sehingga cocok untuk alternatif sarapan yang tinggi serat.

\section{Kadar Karbohidrat}

Hasil uji statistik (Tabel 2) menunjukkan bahwa perlakuan proporsi mocaf, beras hitam, tapioka tidak berpengaruh nyata terhadap kadar karbohidrat flakes Mohiro, sedangkan perlakuan persentase penambahan tepung kacang koro pedang memberikan pengaruh nyata terhadap kadar karbohidrat. Kadar karbohidrat cenderung menurun dengan semakin meningkatnya persentase penambahan tepung kacang koro pedang. Nilai rata-rata karbohidrat flakes Mohiro dari terendah dan tertinggi berturut-turut adalah $76,23 \pm 1,97$ dan $81,85 \pm 1,38 \%$ bb. Kadar karbohidrat flakes Mohiro dipengaruhi oleh kadar karbohidrat bahan baku yang digunakan. Agustia et al. (2017) melaporkan biskuit yang terbuat dari mocaf, garut, dan hati ayam dengan perbandingan 75:10:15 memiliki kadar karbohidrat sebesar $78,71 \%$ bk. Flakes Mohiro mengandung karbohidrat tinggi sebagai penyumbang kalori sehingga sesuai untuk alternatif makanan sarapan.

Tabel 2. Kadar air, kadar abu, kadar protein, kadar lemak, serat pangan total, dan karbohidrat dalam satuan \% pada flakes Mohiro yang dibuat dengan menggunakan mocaf, beras hitam, dan kacang koro pedang

\begin{tabular}{lcccccc}
\hline Formula & Kadar Air & Kadar Abu & Kadar Protein & Kadar Lemak & Serat Pangan & Karbohidrat \\
\hline P1K1 & $10,53 \pm 0,52$ & $1,34 \pm 0,11$ & $3,33 \pm 0,18$ & $5,35 \pm 0,21$ & $15,36 \pm 1,03$ & $79,47 \pm 0,02$ \\
P1K2 & $10,39 \pm 0,12$ & $1,52 \pm 0,35$ & $4,73 \pm 0,47$ & $4,40 \pm 0,18$ & $17,03 \pm 1,14$ & $78,96 \pm 0,06$ \\
P1K3 & $10,96 \pm 0,30$ & $1,59 \pm 0,28$ & $5,85 \pm 0,07$ & $4,21 \pm 0,77$ & $17,32 \pm 2,34$ & $77,41 \pm 1,41$ \\
P2K1 & $9,06 \pm 0,37$ & $1,94 \pm 0,37$ & $3,60 \pm 0,04$ & $3,56 \pm 1,34$ & $13,32 \pm 1,73$ & $81,85 \pm 1,38$ \\
P2K2 & $11,84 \pm 1,08$ & $1,82 \pm 0,45$ & $4,93 \pm 0,19$ & $3,26 \pm 0,91$ & $16,57 \pm 2,87$ & $78,16 \pm 1,34$ \\
P2K3 & $10,63 \pm 0,98$ & $1,51 \pm 0,28$ & $5,75 \pm 0,04$ & $5,56 \pm 2,99$ & $17,43 \pm 3,86$ & $76,56 \pm 1,69$ \\
P3K1 & $9,43 \pm 0,21$ & $1,43 \pm 0,51$ & $5,21 \pm 2,11$ & $4,48 \pm 0,35$ & $15,46 \pm 1,49$ & $79,44 \pm 2,48$ \\
P3K2 & $10,41 \pm 2,45$ & $1,44 \pm 0,19$ & $8,12 \pm 3,61$ & $3,81 \pm 1,00$ & $14,61 \pm 2,23$ & $76,23 \pm 1,97$ \\
P3K3 & $11,04 \pm 0,33$ & $1,35 \pm 0,21$ & $7,34 \pm 1,64$ & $3,05 \pm 0,49$ & $14,21 \pm 2,86$ & $77,23 \pm 2,02$ \\
\hline
\end{tabular}

Tabel 3. Nilai sifat sensori terhadap tekstur, warna, aroma, dan flavor pada flakes Mohiro yang dibuat dengan menggunakan mocaf, beras hitam, dan kacang koro pedang.

\begin{tabular}{|c|c|c|c|c|}
\hline Data & Tekstur & Warna & Aroma & Flavor \\
\hline P1K1 & $2,8 \pm 0,9$ cde & $3,8 \pm 0,7^{a}$ & $3,3 \pm 0,8$ & $2,9 \pm 0,8^{c d}$ \\
\hline P1K2 & $3,6 \pm 0,9 a b$ & $3,1 \pm 0,8 \mathrm{bcd}$ & $3,5 \pm 0,8$ & $3,4 \pm 0,9 a b c$ \\
\hline P1K3 & $2,4 \pm 1,0 \mathrm{de}$ & $3,5 \pm 0,8 a b c$ & $3,4 \pm 0,8$ & $3,0 \pm 0,9 \mathrm{bcd}$ \\
\hline $\mathrm{P} 2 \mathrm{~K} 1$ & $2,3 \pm 0,9$ e & $3,7 \pm 0,9 a b$ & $3,3 \pm 0,8$ & $2,7 \pm 0,9 d$ \\
\hline P2K2 & $3,1 \pm 0,8 \mathrm{bcd}$ & $3,0 \pm 1,1 \mathrm{~cd}$ & $3,3 \pm 0,8$ & $2,9 \pm 0,8 \mathrm{~cd}$ \\
\hline P2K3 & $3,2 \pm 1,0 \mathrm{bc}$ & $3,4 \pm 0,8 \mathrm{abcd}$ & $3,5 \pm 0,9$ & $3,2 \pm 0,9 \mathrm{abcd}$ \\
\hline P3K1 & $3,6 \pm 0,9 a b$ & $3,8 \pm 1,0^{a}$ & $3,7 \pm 0,8$ & $3,6 \pm 0,9 a b$ \\
\hline P3K2 & $4,0 \pm 1$ a & $3,5 \pm 0,7 \mathrm{abc}$ & $3,5 \pm 0,8$ & $3,8 \pm 0,8$ a \\
\hline P3K3 & $2,4 \pm 0,8$ e & $2,9 \pm 0,9 d$ & $3,3 \pm 0,8$ & $2,9 \pm 0,8 \mathrm{~cd}$ \\
\hline
\end{tabular}

Keterangan untuk Tabel 1, 2, dan 3:

Angka yang diikuti superskrip huruf yang berbeda menandakan perbedaan yang nyata $(p<0,05)$

$\mathrm{P} 1=$ proporsi mocaf $:$ beras hitam : tapioka $85: 10: 5$

$\mathrm{P} 2=$ proporsi mocaf $:$ beras hitam $:$ tapioka $75: 20: 5$

$\mathrm{P} 3=$ proporsi mocaf $:$ beras hitam $:$ tapioka $65: 30: 5$

$\mathrm{K} 1=$ tepung kacang koro pedang $10 \%$

$\mathrm{K} 2$ = tepung kacang koro pedang $20 \%$

$\mathrm{K} 3=$ tepung kacang koro pedang $30 \%$ 


\section{Analisis Tekstur}

Kerenyahan flakes merupakan sifat sensori terpenting (Caldwell et al., 2016). Sifat renyah atau krispi yang dikehendaki adalah daya patah atau sifat yang mudah patah seperti pada produk keripik dan chips (Culbertson, 2008). Skor nilai yang dikehendaki berada di antara 3 (agak suka) dan 4 (suka). Sifat kerenyahan flakes diberikan oleh hasil gelatinisasi pati dan penambahan natrium bikarbonat yang sengaja ditambahkan pada adonan flakes (Agustia et al., 2016a).

Analisis statistik (Tabel 3) menunjukkan bahwa perlakuan proporsi mocaf:beras hitam:tapioka dan persentase penambahan tepung kacang koro pedang berpengaruh nyata terhadap tekstur flakes Mohiro. Flakes Mohiro mempunyai skor tekstur berkisar 2,3 $\pm 0,9$ $3,6 \pm 0,9$ (agak suka-suka). Ada kecenderungan bahwa flakes dengan perlakuan penambahan tepung kacang koro pedang yang semakin meningkat memiliki nilai tekstur yang lebih rendah. Hal ini dikarenakan protein dan serat yang semakin tinggi dapat menurunkan volume pengembangan karena terjadi perbedaan sifat viskoelastisitas matriks flakes dan adanya kemampuan crosslinking antara pati dan protein sehingga matriks flakes menjadi lebih rapat dan sukar mengembang saat dipanggang. Selain itu, menurut Chassagne-Berces et al. (2011), serat yang ditambahkan pada produk ektrusi berfungsi sebagai penguat tekstur sehingga semakin tinggi kadar serat maka akan dihasilkan produk dengan tekstur yang lebih kuat dan kokoh akibatnya produk menjadi lebih keras dan daya patahnya meningkat serta dapat juga berpengaruh terhadap sifat rehidrasinya.

\section{Warna flakes}

Hasil analisis statistik (Tabel 3) terhadap warna flakes Mohiro menunjukkan bahwa proporsi mocaf:beras hitam : tapioka dan persentase penambahan tepung kacang koro pedang berpengaruh nyata terhadap warna flakes. Flakes Mohiro mempunyai skor warna berkisar $2,9 \pm 0,6-3,8 \pm 0,7$ (agak suka-suka). Warna flakes Mohiro akan semakin gelap (cokelat) dengan semakin tingginya persentase penambahan tepung kacang koro pedang yang dapat mengurangi kesukaan panelis terhadap flakes. Perubahan warna cokelat ini diakibatkan terjadinya reaksi maillard karena gula pereduksi bereaksi dengan senyawa yang mengandung $\mathrm{NH}_{2}$ (protein, peptida, asam amino, dan amonium) dalam keadaan panas. Hal ini sesuai penelitian Navam et al. (2014), semakin banyak konsentrasi kacang-kacangan yang ditambahaan dengan kecepatan ekstrusi semakin tinggi akan dihasilkan breakfast sereal dengan warna yang semakin gelap dan menurunkan tingkat kesukaannya.

\section{Aroma flakes}

Aroma bahan yang ditambahkan (tepung kacang koro pedang) merupakan faktor yang mempengaruhi aroma langu (khas produk kekacangan) dalam produk flakes yang dihasilkan. Hasil uji statistik (Tabel 3) menunjukkan perlakuan proporsi mocaf:beras hitam:tapioka dan persentase penambahan tepung kacang koro pedang tidak berpengaruh terhadap aroma flakes. Nilai rata-rata aroma flakes terendah dan tertinggi berturut-turut yaitu $3,3 \pm 0,8$ (agak suka) dan $3,7 \pm 0,8$ (suka). Nilai rata-rata aroma flakes tertinggi dimiliki oleh P3K1 (proporsi mocaf-beras hitam-tapioka $=65: 30: 10$, dan persentase penambahan tepung kacang koro pedang $10 \%$ ). Persentase penambahan tepung kacang koro pedang yang semakin tinggi dapat menimbulkan bau lebih langu sehingga menurunkan kesukaan panelis terhadap aroma. Bau langu pada kacang-kacangan ini dikenal dengan beany flavor. Malik et al. (2017), melaporkan penambahan tepung kacang panggang akan menurunkan tingkat kesukaan terhadap aroma pada flakes jagung.

\section{Flavor flakes}

Flavor (cita rasa) flakes Mohiro ternyata sangat dipengaruhi oleh perlakuan persentase penambahan tepung kacang koro pedang. Hasil analisis (Tabel 3 ) oleh tim panelis menunjukkan bahwa perlakuan proporsi mocaf:beras hitam:tapioka dan persentase penambahan tepung kacang koro pedang berpengaruh nyata terhadap flavor flakes. Hasil menunjukkan kecenderungan penurunan nilai flavor flakes dengan semakin tingginya persentase penambahan tepung kacang koro pedang. Nilai flavor flakes berkisar 2,7 $\pm 0,9$ $-3,8 \pm 0,8$ (agak suka-suka).

Flavor "agak suka" pada flakes Mohiro dengan persentase penambahan tepung kacang koro pedang yang semakin meningkat tampaknya diakibatkan oleh adanya aroma langu khas produk kacang akibat aktivitas enzim lipoksigenase. Hal ini sejalan dengan penelitian Malik et al. (2017) yang melaporkan pada flakes jagung dengan penambahan tepung kacang panggang sampai $30 \%$ dapat menurunkan tingkat penerimaan flakes secara keseluruhan, sedangkan penelitian Cheewapramong et al. (2016) melaporkan cereal breakfast meningkat intensitas flavornya pada perlakuan penambahan $30 \%$ tepung kacang panggang yang dihilangkan sebagian lemaknya. Penelitian lain menyebutkan, mi pati sagu yang disubstitusi kacangkacangan (kacang hijau dan kacang merah) sampai 30\% dapat menurunkan kesukaan panelis terhadap flavor mi (Agustia et al., 2016b).

\section{Kesimpulan}

Flakes Mohiro dengan proporsi mocaf:beras hitam:tapioka yang bervariasi dan persentase penambahan tepung kacang koro pedang dapat menghasilkan kadar air, kadar abu, kadar protein, kadar lemak, serat pangan, karbohidrat yang spesifik. Flakes Mohiro ini memiliki sifat sensori yang disukai dari segi tekstur, warna, aroma dan flavor.

\section{Ucapan Terima Kasih}

Peneliti penyampaikan terima kasih kepada Kementerian Riset, Teknologi dan Pendidikan Tinggi yang telah membiayai penelitian ini melalui Program Penelitian Peningkatan Kompetensi Dana BLU Unsoed Tahun 2018 dengan SK Ketua LPPM Unsoed Nomor : Kept. 2351/UN23.14/PN.01.00/2018. 


\section{Daftar Pustaka}

Agustia, F.C., Rukmini, H.S., Naufalin, R. $2016 a$. Utilization of pregerminated jackbean and soybean for increasing the protein content of instant tiwul. Proceeding. 162-169. ISBN : 978602-61032-1-5. Page 163-169.

Agustia, F.C., Subardjo, Y.P., Sitasari, S. 2016b. Formulasi dan karakterisasi mi bebas gluten tinggi protein berbahan pati sagu yang disubstitusi tepung kacang-kacangan. Jurnal Gizi dan Pangan 11(3):183-190. DOI: 10.25182/jgp.2016.11.3.183190.

Agustia, F.C., Subardjo, Y.P., Sari, H.P. 2017. Pengembangan biskuit mocaf-garut dengan substitusi hati sebagai alternatif biskuit tinggi zat besi untuk balita. Jurnal Gizi dan Pangan 12(2):129-138. DOI:10.25182/jgp.2017.12.2.129138.

Agustia, F.C., Rukmini, H.S., Naufalin, R. 2018. Formulasi tiwul instan tinggi protein dari tepung ubi kayu yang disubstitusi tepung koro pedang dan susu skim. Jurnal Aplikasi Teknologi Pangan 7(1):15-20.DOI: 10.17728/jatp.2132.

Al-Baarri, A.N., Legowo, A.M., Rizqiati, H., Widayat, Septianingrum, A., Sabrina, H. N., Mochtar, R. C.P.R. 2018. Application of iota and kappa carrageenans to traditional several food using modified cassava flour. IOP Conference Series: Earth and Environmental Science 102(012056). DOI:10.1088/1755-1315/102/1/012056.

Andriansyah, R.C.E., Rahman, T., Herminiati, A., Rahman, N., Luthfiyanti, R. 2017. Characteristics of chemical and functional properties of modified cassava flour (manihot esculenta) by autoclavingcooling cycles method. IOP Conference Series Earth and Environmental Science 101(1):012023. DOI:10.1088/1755-1315/101/1/012023.

Ariyantoro, A.R., Rahmawanti, D., Ikarini, I. 2016. Karakteristik fisikokimia tepung koro pedang (Canavalia Ensiformis) termodifikasi dengan variasi konsentrasi asam laktat dan lama perendaman. Agritech 36(1):1-6. DOI: 10.22146/agritech.10675.

Bakar, J., Hin, Y.S. 2007. High-protein rice-soya breakfast cereal. 2007. Journal of Food Processing and Preservation 8(3-4):163174.DOI: 10.1111/j.1745-4549.1985.tb00695.x.

Baker, D.,Holden, J.M. 2006. Fiber in breakfast cereal. Journal of Food Science 46(2):396-398 DOI:10.1111/j.1365-2621.1981.tb04869.x.

Batubara, I., Maharni, M., Sadiah, S. 2017. The potency of white rice (Oryza sativa), black rice (Oryza sativa L. Indica) and red rice (Oryza nivara) as antioxidant and tyrosinase inhibitor. Journal of Physic: Confrence Series 824(1):1-6. DOI: 10.1088/1742-6596/824/1/012017.

Caldwell, E.F., Kadan, R.S., McKeehen, J.D. 2016. Cereals: Breakfast Cereals. Encyclopedia of Food Grains. DOI: 10.1016/B978-0-12-3944375.00143-1.
Chassagne-Berces, S., Leitner, M., Melado, A., Barreiro, P., Correa, E.C., Blank, I., Gumy, J., Chanvrier, H. 2011. Procedia Food Science 1 (2011) 17 - 23. DOI: 10.1016/j.tifs.2012.06.008.

Cheewapramong, P., Riaz, M.N., Rooney, L.W., Lusas, E.W. 2016. Use of partially defatted peanut flour in breakfast cereal flakes. Cereal Chemistry 79(4):586-592. DOI: 10.1094/CCHEM.2002. 79.4 .586 .

Croitoru, C., Muresan, C., Turturica, M., Stanciuc, N., Andronoiu, D.G., Dumitrascu, L., Barbu, V., Enachi, E. Horincar, G., Râpeanu, G. 2018. Improvement of quality properties and shelf life stability of new formulated muffins based on black rice. Molecules 23(11): 30-47. DOI: 10.3390/molecules23113047.

Culbertson, J.D. 2008. Grain, Cereal: Ready-to-Eat Breakfast Cereals. Food Processing: Principles and Application. DOI: 10.1002/9780470290118. ch12.

Hudiyanti, D., Arya, A.P., Siahaan, P., Suyati, L. 2015. Chemical composition and phospholipids content of indonesian jack bean (Canavalia ensivormis $L$ ). Oriental Journal of Chemistry 31(4):2043-2046. DOI: $10.13005 /$ jc/310423.

Hsieh, C.F., Liu, W., Whaley, J.K., Shi, Y.C. 2019. Structure, properties, and potential applications of waxy tapioca starches - a review. Trends in Food Science \& Technology 83:225-234. DOI: 10.1016/j.tifs.2018.11.022.

Kang, Y.M., Kim, J.H., Rico, C.W., Nam, S.H. 2011. A comparative study on the physicochemical characteristics of black rice varieties. International Journal of Food Properties 14(6):1241-1254. DOI: 10.1080/10942911003637350.

Kusharto, C.M. 2006. Serat makanan dan peranannya bagi kesehatan. Jurnal Gizi dan Pangan 1(2):4554. DOI: 10.25182/jgp.2006.1.2.45-54.

Malik, A.A., Bhat, A., Kour, H., Ahmad, N., Gupta, P. 2017. Processing and assessment of quality characteristics of corn-peanut flakes. J. Food.

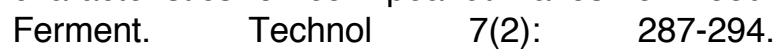
DOI:10.5958/2321-5771.2017.00039.4.

Moskowitz, H.R., Beckley, J.H., and Anna VA.2012. Sensory and Consumer Research in Food Product Design and Development, Second Edition. Blackwell Publishing Ltd. and the Institute of Food Technologists. ISBN 9781119945970. DOI:10.1002/9781119945970.

Murdiati, A., Anggrahini, A., Supriyanto, Alim, A. 2015. Peningkatan kandungan protein mi basah dari tapioka dengan substitusi tepung koro pedang putih (Canavalia ensiformis L). Agritech 35(3):251-260. DOI: 10.22146/agritech.9334.

Navam, S.H., Tajudini, A.L., Srinivas, J.R., Sivarooban, T., Kristofor, R.B. 2014. Physio-chemical and sensory properties of protein-fortified extruded breakfast cereal/snack formulated to combat protein malnutrition in developing countries. Journal Food Process Technol 5(8). DOI: 10.4172/2157-7110.1000359. 
Nwokolo, E. 1996. Food and Feed from Legumes and Oilseeds, Chapter Six : Jack Bean (Canavalia ensiformis L. D.C). Chapman \& Hall. DOI: 10.1007/978-1-4613-0433-3_6.

Silva, P.A., Assis, G.K., Carvalho, A.V., Simoes, M.G. 2011. Development and characterization of an extruded breakfast cereal from cassava enriched with milk whey protein concentrate. Brazilian Journal of Food technology 14(4):260-266. DOI: 10.4260/BJFT2011140400031.

SNI (Standar Nasional Indonesia). Syarat Mutu Susu Sereal SNI 01-427-1996. 1996. Badan Standarisasi Nasional. Jakarta.

Sukasih, E., Setyadjit. 2012. Formulasi pembuatan flake berbasis talas untuk makanan sarapan (breakfast meal) energi tinggi dengan metode oven. Jurnal
Pascapanen 9(2):70-76. DOI: 10.21082/jpasca. v9n2.2012.70-76.

Sulistyo, J., Nakahara, K. 2014. Cassava flour modification by microorganism. Conference: The 1st International Symposium on Microbial Technology for Food and Energy, Kasetsart University, Bangkok, Thailand, November. Page 1-8. DOI: $10.13140 / 2.1 .3702 .4966$.

Supadmi, S., Murdiati, A., Rahayu, E.S. 2016. Komposisi gizi, indeks warna putih, dan profil granula pati pada modified cassava flour (mocaf) yang difortifikasi dengan iodium. Media Gizi Mikro Indonesia 8(1):65-78. DOI: 10.22435/mgmi.v8i1. 7688.65-78 